\title{
Effect of Coated Surfaces influencing Screw Loosening in Implants: A Systematic Review and Meta-analysis
}

\author{
${ }^{1}$ Abinaya Kannan, ${ }^{2}$ Suresh Venugopalan, ${ }^{3}$ Dhanraj M Ganapathy
}

\begin{abstract}
Introduction: The abutment screw loosening has been a common clinical mishap affecting the success of the implant in the long run. With repeated insertion and removal of the implant abutment screw during fabrication of the restoration, frictional wear at the microscopic level in the screw threads had been reported.
\end{abstract}

Aim: To assess the effectiveness of screw coating in minimizing abutment screw loosening in dental implants in literature.

Results: A database search yielded a total of 14 articles out of which 8 were excluded based on the title and abstracts not relevant to the topic of our interest and 6 were included based on the core data. The six articles were reviewed, and four articles were consolidated to perform the meta-analysis. All the four studies showed a similar expression of outcome measure; the detorque values were expressed in $\mathrm{Ncm}$.

The $\chi^{2}=144.71, d f=3, p<0.00001$, and $I^{2}=98 \%$. Hence, a Random Effect model with $95 \%$ confidence interval was chosen for meta-analysis. The overall effect observed in the metaanalysis was $Z=0.36, p=0.72$, and no statistically significant differences were observed between the coated and noncoated screws with respect to detorque values.

Conclusion: This meta-analysis inferred that there is no difference between the coated and noncoated screws with respect to screw loosening.

Clinical significance: Noncoated screws are equally effective as coated screws with respect to abutment loosening in endosseous implants. Hence, the additional cost and technique sensitivity incurred with powdered screws may not drastically improve the rate of failure due to screw loosening.

Keywords: Abutment screw, Coated abutment screws, Screw loosening, Surface modification.

How to cite this article: Kannan A, Venugopalan S, Ganapathy DM. Effect of Coated Surfaces influencing Screw Loosening in Implants: A Systematic Review and Meta-analysis. World J Dent 2017;8(6):496-502.

Source of support: Nil

Conflict of interest: None

${ }^{1-3}$ Department of Prosthodontics, Saveetha Dental College Saveetha University, Chennai, Tamil Nadu, India

Corresponding Author: Abinaya Kannan, Department of Prosthodontics, Saveetha Dental College, Saveetha University Chennai, Tamil Nadu, India, Phone: +917598445929, e-mail: dr.abinayakannan@gmail.com

\section{INTRODUCTION}

Implant, as a treatment modality, has been widely accepted for replacing single or multiple missing teeth. For successful implant therapy and its clinical longevity, the condition of the periodontium and systemic conditions are not the only determining factors. Material aspects and mechanical features of the implant and its abutment screw also play a vital role in it.

Prosthetic screw loosening has been one of the most common clinically encountered problems in implant cases in the long run and has been known to greatly affect its longevity and success. ${ }^{1-5}$ Various factors are attributed to its loosening such as screw design, elasticity of the bone, elasticity of the screw joint, initial preload, friction coefficient, applied torque, and rate of tightening. ${ }^{4-11}$

The implant-abutment joint is a dynamic system that exhibits changes continuously. The internal surface of the implant undergoes a series of changes with fabrication of restoration. With insertion of the healing abutment, impression components, and definitive abutments, the surface morphology of the internal portion of the implant starts showing deterioration even before the definitive restoration is even placed. With clinical procedures that mandate the insertion and removal of abutment screw, a microstructural deterioration of the abutment screw surface morphology may be observed.

As deterioration progresses, the detorque values were found to decrease when compared with the torque values and once it reaches its threshold, the threads of the abutment screw disengage from the grooves of the internal surface of the implant and the abutment starts revolving around its own axis posing a clinical problem.

It is, therefore, necessary to address this issue to ensure long-term success of dental implants. Studies show that with surface modification of abutment screws, there was a significant difference in the tightening and reverse torque values and surface morphology of the abutment screws under scanning electron microscopy (SEM).

\section{AIM}

The aim of the systematic review was to analyze scientific evidence in the past and present comparing the rate of wear of coated abutment screw surfaces that have been subjected to loading with that of noncoated abutment screw surfaces through torque-detorque values and SEM 
study and support the concept that with surface modification, abutment screw elicits resistance to screw loosening.

\section{Structured Question}

Is there a difference in screw loosening between coated and noncoated abutment screws?

\section{Null Hypothesis}

There is no difference in resistance to screw loosening between coated and noncoated abutment screws in literature.

\section{Alternate Hypothesis}

There is a difference in resistance to screw loosening between coated and noncoated abutment screws in literature.

\section{PICO Analysis}

- Population: Implants and their structural components,

- Intervention: Coating/surface modification of abutment screws,

- Comparison: Noncoated/nonsurface modified abutment screws,

- Outcome: Torque values, reverse torque values, friction coefficient measures, and surface characteristic changes under SEM.

\section{MATERIALS AND METHODS}

A review of literature of studies on resistance to screw loosening in coated $v$ s noncoated abutment screws that have been published was carried out without a filter on publication dates and all articles of the past were retrieved (Fig. 1).

\section{Sources used}

For identification of studies included or considered for this review, detailed search strategies were developed for the database searched. Search was initiated with the combination of controlled vocabulary-free text terms. The keywords employed in this search were broadly classified into five categories describing population, intervention, comparison, outcome, and the type of study. Keywords within each group were combined using operator (odds ratio) OR and the searches of individual groups were combined using operator AND, to retrieve articles electronically.

\section{Searched Databases}

- PubMed

- Medline

\section{Inclusion Criteria}

\section{Types of Studies}

In vitro study, in vivo study, clinical trial, randomized controlled trial, lab study, dental material study, or SEM study dealing with abutment screw loosening.

\section{Exclusion Criteria}

- Studies dealing with ceramic and other polymer screw loosening

- Studies dealing with screw loosening due to screw fracture

\section{RESULTS}

Out of the 14 articles obtained from electronic search, 8 were excluded based on the title and abstract compared with the topic of our interest and 6 were included based on the core data. The six articles were reviewed, and four articles were consolidated to perform meta-analysis as depicted in Flow Chart 1.

Four studies were consolidated for meta-analysis. All the studies showed a similar expression of outcome measure; the detorque values were expressed in $\mathrm{Ncm}$. The mean detorque values for coated and noncoated screws, respectively, were $20.89 \pm 8$ and $19.96 \pm 7.1 \mathrm{Ncm}$. The treatment effect measured in this analysis was the difference between the means of coated and noncoated abutment screws, respectively. Random effect model with 95\% confidence interval was chosen for meta-analysis. The $\chi^{2}=144.71, \mathrm{df}=3, \mathrm{p}<0.00001$, and $I^{2}=98 \%$ and the overall effect size observed in the meta-analysis was $Z=0.36, p=0.72$. Hence, it could be inferred that there is no statistically significant difference between the coated and noncoated screws with respect to screw loosening based on detorque values (Table 1).

\section{DISCUSSION}

With increasing dental awareness, the scope of implant therapy has increased manifold. This most advocated therapy for replacement of teeth, however, holds many prosthetic complications such as crown loosening because of short abutments, esthetic failures, ceramic fracture, and inappropriate proximal contacts leading to food accumulation, and associated peri-implant diseases. The prosthetic component failures of the dental implant have also been frequently associated with screw loosening or fracture. ${ }^{1-3}$

Nigro et $\mathrm{al}^{4}$ had mentioned in their article on screw loosening that among the types of mechanical failures, abutment screw loosening is still the most frequently reported in literature. Kano et $\mathrm{al}^{5}$ stated that factors related to screw loosening are various, including inadequate 


\begin{tabular}{|c|c|c|c|c|}
\hline Search & $\begin{array}{l}\text { Add to } \\
\text { builder }\end{array}$ & Query & $\begin{array}{l}\text { Items } \\
\text { found }\end{array}$ & Time \\
\hline$\# 98$ & Add & 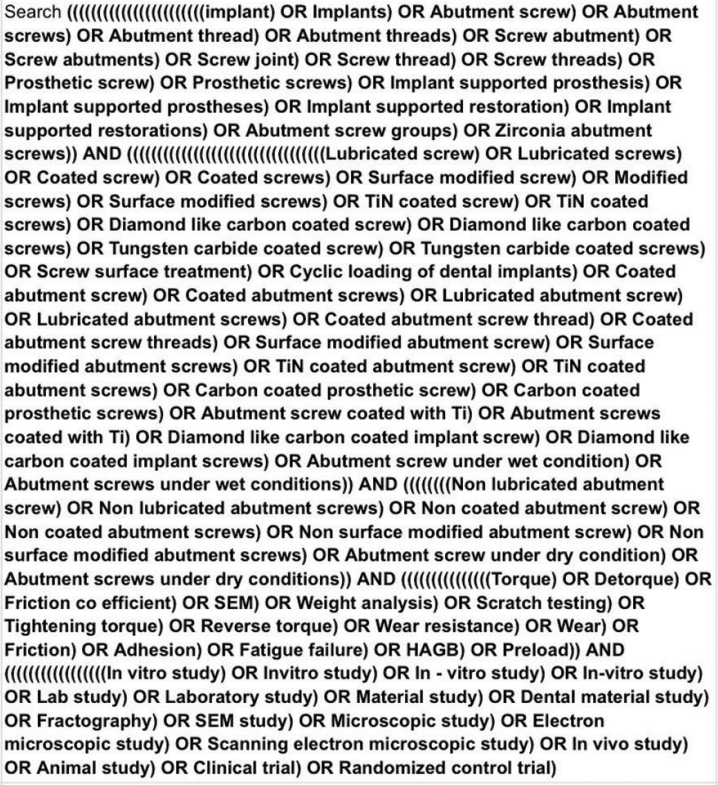 & 14 & 00:56:16 \\
\hline$\# 97$ & Add & $\begin{array}{l}\text { Search (((()((()((()(((In vitro study) OR Invitro study) OR In - vitro study) OR In-vitro } \\
\text { study) OR Lab study) OR Laboratory study) OR Material study) OR Dental material } \\
\text { study) OR Fractography) OR SEM study) OR Microscopic study) OR Electron } \\
\text { microscopic study) OR Scanning electron microscopic study) OR In vivo study) } \\
\text { OR Animal study) OR Clinical trial) OR Randomized control trial }\end{array}$ & 4003380 & 00:55:51 \\
\hline \#96 & Add & Search Randomized control trial & $\underline{208979}$ & 00:54:41 \\
\hline$\# 95$ & Add & Search Clinical trial & 1013175 & 00:54:31 \\
\hline \#94 & Add & Search Animal study & 1800094 & 00:54:22 \\
\hline$\# 93$ & Add & Search In vivo study & $\underline{289602}$ & $00: 54: 14$ \\
\hline$\# 92$ & Add & Search Scanning electron microscopic study & 131968 & $00: 53: 56$ \\
\hline \#1 & Add & Search Electron microscopic study & 451633 & $00: 53: 43$ \\
\hline$\# 90$ & Add & Search Microscopic study & $\underline{62566}$ & 00:53:30 \\
\hline$\# 89$ & Add & Search SEM study & 40091 & $00: 53: 20$ \\
\hline$\# 88$ & Add & Search Fractography & 184 & $00: 53: 08$ \\
\hline$\# 87$ & Add & Search Dental material study & $\underline{76274}$ & $00: 52: 59$ \\
\hline$\# 86$ & Add & Search Material study & 194785 & 00:52:50 \\
\hline$\# 85$ & Add & Search Laboratory study & $\underline{617489}$ & 00:52:39 \\
\hline$\# 84$ & Add & Search Lab study & 135227 & $00: 52: 29$ \\
\hline$\# 83$ & Add & Search In-vitro study & 514604 & $00: 52: 20$ \\
\hline$\# 82$ & Add & Search In - vitro study & $\underline{514604}$ & 00:52:07 \\
\hline$\# 81$ & Add & Search Invitro study & $\underline{275}$ & $00: 51: 53$ \\
\hline$\# 80$ & $\underline{\text { Add }}$ & Search In vitro study & $\underline{514604}$ & $00: 51: 35$ \\
\hline$\# 79$ & Add & $\begin{array}{l}\text { Search ((l(()((()((((Torque) OR Detorque) OR Friction co efficient) OR SEM) OR } \\
\text { Weight analysis) OR Scratch testing) OR Tightening torque) OR Reverse torque) } \\
\text { OR Wear resistance) OR Wear) OR Friction) OR Adhesion) OR Fatigue failure) OR } \\
\text { HAGB) OR Preload }\end{array}$ & $\underline{960465}$ & $00: 51: 23$ \\
\hline$\# 78$ & Add & Search Preload & $\underline{7035}$ & $00: 50: 28$ \\
\hline$\# 77$ & Add & Search HAGB & $\underline{37}$ & $00: 50: 17$ \\
\hline$\# 76$ & Add & Search Fatigue failure & 7225 & $00: 50: 08$ \\
\hline$\# 75$ & Add & Search Adhesion & $\underline{225326}$ & $00: 49: 56$ \\
\hline
\end{tabular}

Fig. 1: Search methodology

Flow Chart 1: Search flowchart

Potentially relevant studies identified and screened for retrieval $=14$

Studies excluded after examination of title and abstract $=8$

Studies retrieved for more detailed evaluation $=6$

Studies excluded from meta-analysis $=2$

Studies consolidated for meta-analysis $=4$ preload torquing, inaccurate fit of framework, poor component fit, flexure of framework, settling, debris trapped in screw receptor, screw design, and bone elasticity.

Jemt et $\mathrm{al}^{2}$ in their study found abutment screw loosening to be as high as $45 \%$ with implant single crowns. Jung et $\mathrm{al}^{6}$ calculated the cumulative incidence of connection-related complications (screw loosening, $12.7 \%$; screw fracture, $0.35 \%$ ) during 5 years of clinical service.

The abutment screw loosening or fracture is also associated with frequent insertion and removal of the abutment screws during the various clinical and laboratory procedures; the abutment screw undergoes wear at 
Effect of Coated Surfaces influencing Screw Loosening in Implants

Table 1: Meta-analysis—detorque values

\begin{tabular}{|c|c|c|c|c|c|c|c|c|c|c|}
\hline \multirow{2}{*}{$\begin{array}{l}\text { Study or } \\
\text { subgroup }\end{array}$} & \multicolumn{3}{|c|}{ Coated screws } & \multicolumn{3}{|c|}{ Noncoated screws } & \multirow[b]{2}{*}{ Weight } & \multirow{2}{*}{$\begin{array}{l}\text { Mean difference } I V \text {, } \\
\text { random, } 95 \% \mathrm{Cl}\end{array}$} & \multirow{2}{*}{\multicolumn{2}{|c|}{$=$}} \\
\hline & Mean & $S D$ & Total & Mean & $S D$ & Total & & & & \\
\hline Bacchi A 2015 & 22.4 & 1.14 & 20 & 26.4 & 1.16 & 20 & $25.9 \%$ & $-4.00(-4.71,-3.29)$ & & \\
\hline Juliana 2012 & 13.62 & 1.68 & 9 & 11.25 & 4.71 & 9 & $23.2 \%$ & $2.37(-0.90,5.64)$ & & \\
\hline Kim HJ 2007 & 16.05 & 1.23 & 7 & 14.69 & 2.03 & 7 & $25.2 \%$ & $1.36(-0.40,3.12)$ & Favours coated screws & $\begin{array}{l}0 \\
\text { Favours noncoated screws }\end{array}$ \\
\hline Nigro F 2010 & 31.5 & 1.2 & 10 & 27.5 & 1.5 & 10 & $25.7 \%$ & $4.00(2.81,5.19)$ & & \\
\hline Total $(95 \% \mathrm{Cl})$ & & & 46 & & & 46 & $100.0 \%$ & & & \\
\hline
\end{tabular}

Heterogeneity: Tau $^{2}=22.50 ; \chi^{2}=144.71, \mathrm{df}=3(p<0.00001) ; I^{2}=98 \%$; Test for overall effect $Z=0.36(p=72)$

microscopic level with each episode. With an increase in this wear, there is a subsequent decrease in the detorque values, and during further prosthetic loading, the screw loses its threshold limit to engage into the grooves, and it either starts revolving around its own axis or tends to fracture. $^{7-9}$

Factors related to screw loosening are various, including poor tightening (inadequate preload), inaccurate fit of framework, poor component fit, flexure of framework, settling, debris trapped in screw receptor, screw design, and bone elasticity. $4,10,11,13-41$

Various methods to combat this potential problem of screw loosening would include ensuring an adequate preload which supersedes the masticatory force, proper fit of the component, a considerably rigid framework, care taken to prevent entrapment of debris at the screw receptor site, choosing an appropriate screw design based on the nature of the bone, and coating of abutment screws.

Coating of abutment screws has been done in many ways including radiofrequency sputtering, physical vapor deposition, radiofrequency plasma-assisted chemical vapor deposition, plasma-enhanced chemical vapor deposition, hot filament chemical vapor deposition, filling the inner threads of the implants with artificial saliva, cathodic arc deposition, and microwave plasma-

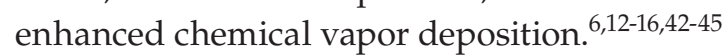

Abutment screws are available in various materials such as titanium, zirconium, and gold. ${ }^{4,10,11}$ However, titanium is the most preferred owing to its compatibility and success rate. To bring about an increase in the detorque values and prevent screw loosening, various surface modifications had been done on the abutment screws using carbon, diamond-like carbon, titanium nitride, and gold. 6,16-18 The outcomes had been measured through detorque values, weight analysis, preload assessment, and SEM study (Table 2). 4,6,16,19

While the study by Kim et $\mathrm{al}^{12}$ shows a mean value of 1.36 lying close to the weighted mean difference (WMD), studies by Nigro et $\mathrm{al}^{4}$ and Bacchi et $\mathrm{al}^{17}$ had their mean values showing further deviation from WMD with values of 4.0 and -4.0 respectively.
Table 2: Types of outcome measures

\begin{tabular}{l}
\hline Types of outcome measures \\
\hline Torque-detorque values \\
Friction coefficient values \\
Measures of weight \\
Surface characteristics and associated changes under SEM \\
\hline
\end{tabular}

Although Bacchi et al's ${ }^{17}$ study is contradictory and favors noncoated screws, its significant effect on the outcome of the meta-analysis may be attributed to its higher sample size (Table 3).

Under SEM study performed on coated and noncoated screws, the surface topography of the coated and noncoated abutment screws subjected to loading cycles was assessed. In all studies, the authors inferred that noncoated abutment screws showed more wear when compared with coated ones.

Jörn et $\mathrm{al}^{19}$ simulated the friction coefficient of dry and wet conditions in abutment screws, assigned a calculated preload, and evaluated the corresponding stress values accordingly. She suggested higher preload values in friction coefficients corresponding to wet (coated) conditions, thereby vouching coating of abutment screws over conventional ones in resistance to screw loosening. Jung et $\mathrm{al}^{6}$ compared the weight difference between coated and noncoated abutment screws after multiple insertion cycles, and there was a positive correlation for weight loss and surface abrasion, which could affect the torque values.

Of the several factors influencing abutment screw loosening, coating the screws with various methods was assumed as a potential remedial measure to combat screw loosening. The difficulties with screw loosening include utilization of advanced technology to coat the screws, which will reflect in additional time consumption and escalated costs. However, this present meta-analysis has observed a similar behavior between coated and noncoated abutment screws with respect to screw loosening. Nevertheless, additional methods of powder coating and different choice of materials for abutment screws, which might influence screw loosening, need to be explored by further research. Outcome variables and CEBM level of evidence of various studies are mentioned in Tables 4 and 5 respectively.. 


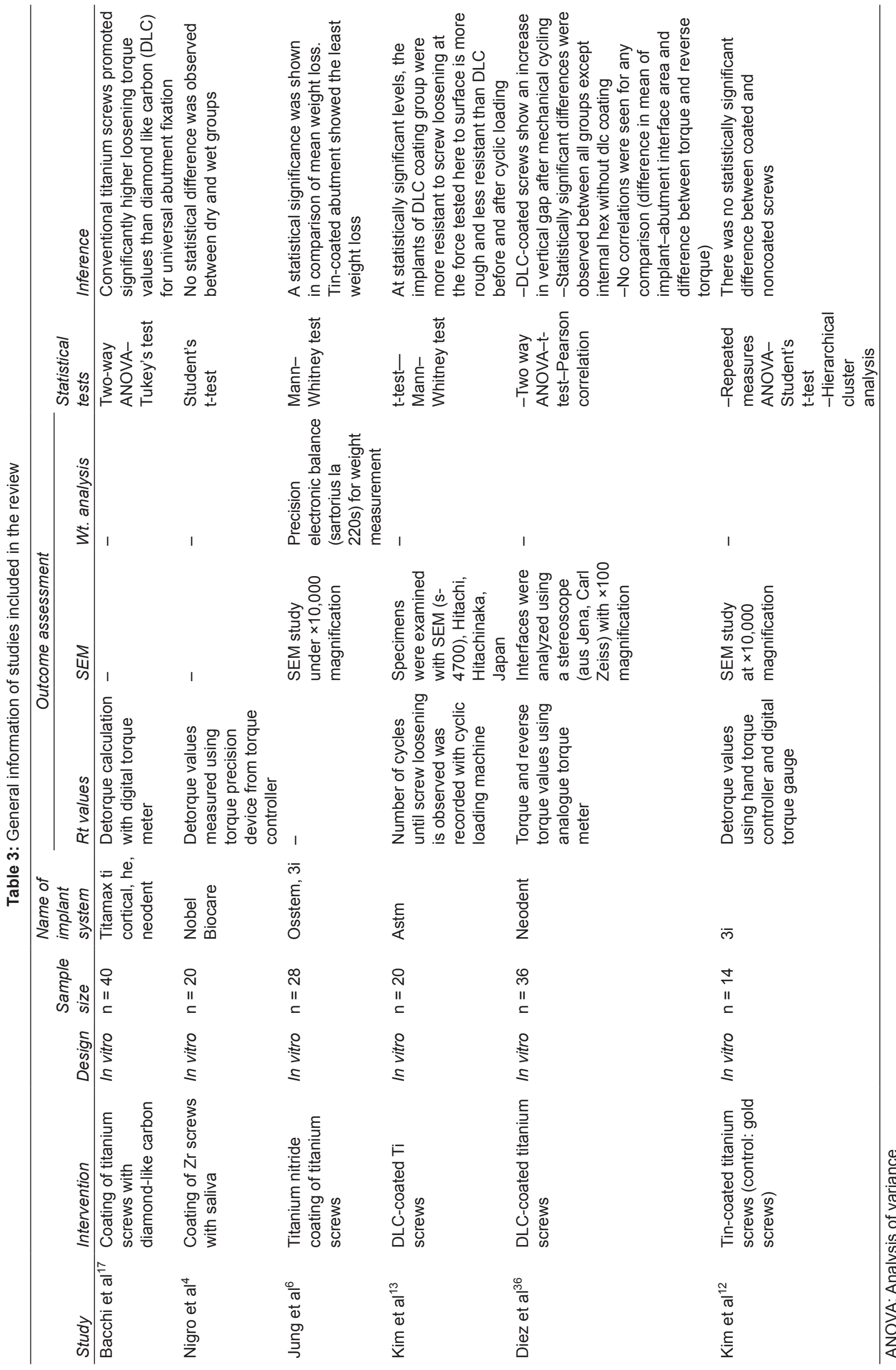


Effect of Coated Surfaces influencing Screw Loosening in Implants

\begin{tabular}{|c|c|c|}
\hline Study & \multicolumn{2}{|c|}{ Intervention } \\
\hline Bacchi et al ${ }^{17}$ & \multicolumn{2}{|c|}{ Coating of Ti screws with DLC } \\
\hline Nigro et al ${ }^{4}$ & \multicolumn{2}{|c|}{ Coating of $\mathrm{Zr}$ screws with saliva } \\
\hline Jung et $\mathrm{al}^{6}$ & \multicolumn{2}{|c|}{ Coating of Ti screws with TiN } \\
\hline Kim et $\mathrm{al}^{13}$ & \multicolumn{2}{|c|}{ Coating of Ti screws with DLC } \\
\hline Diez et al ${ }^{36}$ & \multicolumn{2}{|c|}{ Coating of Ti screws with DLC } \\
\hline Kim et $\mathrm{al}^{12}$ & \multicolumn{2}{|c|}{ Coating of Ti screws with TiN } \\
\hline Study & Study design & $\begin{array}{l}\text { CEBM level } \\
\text { of evidence }\end{array}$ \\
\hline Bacchi et al ${ }^{17}$ & In vitro study & Level 5 \\
\hline Nigro et $a^{4}$ & In vitro study & Level 5 \\
\hline Jung et $\mathrm{al}^{6}$ & In vitro study & Level 5 \\
\hline Kim et $\mathrm{al}^{13}$ & In vitro study & Level 5 \\
\hline Diez et al ${ }^{36}$ & In vitro study & Level 5 \\
\hline Kim et $\mathrm{al}^{12}$ & In vitro study & Level 5 \\
\hline
\end{tabular}

\section{CONCLUSION}

This meta-analysis inferred that there is no statistical difference between the coated and noncoated screws with respect to dental abutment screw loosening. Hence, both can be used in suitable clinical situations.

\section{REFERENCES}

1. Goodacre CJ, Bernal G, Rungcharassaeng K, Kan JY. Clinical complications with implants and implant prostheses. J Prosthet Dent 2003 Aug;90(2):121-132.

2. Jemt T, Lekholm U, Gröndahl K. 3-year follow-up study of early single implant restorations ad modum branemark. Int J Periodont Rest Dent 1989;10(5)340-349.

3. Jemt T, Laney WR, Harris D, Henry PJ, Krogh PH Jr, Polizzi G, Zarb GA, Herrmann I. Osseo integrated implants for single tooth replacement: a 1-year report from a multicenter prospective study. Int J Oral Maxillofac Implants 1991;6(1): 29-36.

4. Nigro F, Sendyk CL, Francischone CE Jr, Francischone CE. Removal torque of zirconia abutment screws under dry and wet conditions. Braz Dent J 2010;21(3)225-228.

5. Kano SC, Binon P, Bonfante G, Curtis DA. Effect of casting procedures on screw loosening in UCLA-type abutments. J Prosthodont 2006 Mar-Apr;15(2):77-81.

6. Jung SW, Son MK, Chung CH, Kim HJ. Abrasion of abutment screw coated with TiN. J Adv Prosthodont 2009 Jul;1(2): 102-106.

7. Jo JY, Yang DS, Huh JB, Heo JC, Yun MJ, Jeong CM. Influence of abutment materials on the implant-abutment joint stability in internal conical connection type implant systems. J Adv Prosthodont 2014 Dec;6(6):491-497.

8. Adell R, Eriksson B, Lekholm U, Brånemark PI, Jemt T. Longterm follow-up study of Osseo integrated implants in the treatment of totally edentulous jaws. Int J Oral Maxillofac Implants 1990 Winter;5(4):347-359.

9. Rangert $\mathrm{BO}$, Jemt $\mathrm{T}$. Forces and moments on brånemark implants. Int J Oral Maxillofac Implants 1989;4(3):241-247.

10. Khraisat A, Abu-Hammad O, Al-Kayed AM, Dar-Odeh N. Stability of the implant/abutment joint in a single-tooth external-hexagon implant system: clinical and mechanical review. Clin Implant Dent Relat Res 2004;6(4)222-229.

11. Jörnéus L, Jemt T, Carlsson L. Loads and designs of screw joints for single crowns supported by Osseo integrated implants. Int J Oral Maxillofac Implants 1992;7(3):353-359.

12. Kim HJ, Choe HC, Chung CH. Effect of TiN coating of abutment screw on detorque force. J Kor Acad Prosthodont 2007 Jun;45:329-338.

13. Kim SK, Lee JB, Koak JY, Heo SJ, Lee KR, Cho LR, Lee SS. An abutment screw loosening study of a diamond like carbon-coated CP titanium implant. J Oral Rehabil 2005 May;32(5):346-350.

14. Xie Y, Zhou J, Wei Q, Yu ZM, Luo H, Zhou B, Tang ZG. Improving the long-term stability of $\mathrm{Ti}_{6} \mathrm{Al}_{4} \mathrm{~V}$ abutment screw by coating micro/nano-crystalline diamond films. J Mech Behav Biomed Mater 2016 Oct; 63:174-182.

15. Yang L, Sheldon BW, Webster TJ. Orthopedic nano diamond coatings: control of surface properties and their impact on osteoblast adhesion and proliferation. J Biomed Mater Res A 2009 Nov;91(2):548-556.

16. Corazza PH, de Moura Silva A, Cavalcanti Queiroz JR, Salazar Marocho SM, Bottino MA, Massi M, de Assunção e Souza RO. Carbon film coating of abutment surfaces: effect on the abutment screw removal torque. Implant Dent 2014 Aug;23(4):434-438.

17. Bacchi A, Regalin A, Bhering CL, Alessandretti R, Spazzin AO. Loosening torque of universal abutment screws after cyclic loading: influence of tightening technique and screw coating. J Adv Prosthodont 2015 Oct;7(5):375-379.

18. Park JK, Choi JU, Jeon YC, Choi KS, Jeong CM. Effects of abutment screw coating on implant preload. J Prosthodont 2010 Aug;19(6):458-464.

19. Jörn D, Kohorst P, Besdo S, Rücker M, Stiesch M, Borchers L. Influence of lubricant on screw preload and stresses in a finite element model for a dental implant. J Prosthet Dent 2014 Aug;112(2):340-348. 
20. Geringer A, Diebels S, Nothdurft FP. Influence of superstructure geometry on the mechanical behaviour of zirconia implant abutments: a finite element analysis. Biomed Tech (Berl) 2014 Dec;59(6):501-506.

21. Hirata R, Bonfante EA, Machado LS, Tovar N, Coelho PG. Mechanical evaluation of four narrow-diameter implant systems. Int J Prosthodont 2014 Jul-Aug;27(4):359-362.

22. Bernardes SR, da Gloria Chiarello de Mattos M, Hobkirk J, Ribeiro RF. Loss of preload in screwed implant joints as a function of time and tightening/untightening sequences. Int J Oral Maxillofac Implants 2014 Jan-Feb;29(1):89-96.

23. Assunção WG, Delben JA, Tabata LF, Barao VA, Gomes EA, Garcia IR Jr. Preload evaluation of different screws in external hexagon joint. Implant Dent 2012 Feb;21(1):46-50.

24. Del'Acqua MA, Chávez AM, Compagnoni MA. Accuracy of impression techniques for an implant-supported prosthesis. Int J Oral Maxillofac Implants 2010 Jul-Aug;25(4).715-721.

25. Nothdurft F, Pospiech P. Prefabricated zirconium dioxide implant abutments for single-tooth replacement in the posterior region: evaluation of peri-implant tissues and superstructures after 12 months of function. Clin Oral Implants Res 2010 Aug;21(8):857-865.

26. Stüker RA, Teixeira ER, Beck JC, Costa NP. Preload and torque removal evaluation of three different abutment screws for single standing implant restorations. J Appl Oral Sci 2008 Jan/Feb;16(1):55-58.

27. Guda T, Ross TA, Lang LA, Millwater HR. Probabilistic analysis of preload in the abutment screw of a dental implant complex. J Prosthet Dent 2008 Sep;100(3):183-193.

28. Elter C, Heuer W, Demling A, Hannig M, Heidenblut T, Bach FW, Stiesch-Scholz M. Supra-and subgingival biofilm formation on implant abutments with different surface characteristics. Int J Oral Maxillofac Implants 2008;23: 327-334.

29. Becker W, Becker BE, Huffstetler S. Early functional loading at 5 days for Brånemark implants placed into edentulous mandibles: a prospective, open-ended, longitudinal study. J Periodontol 2003;74(5)695-702.

30. Tzenakis GK, Nagy WW, Fournelle RA, Dhuru VB. The effect of repeated torque and salivary contamination on the preload of slotted gold implant prosthetic screws. J Prosthet Dent 2002 Aug;88(2):183-191.

31. Al-RafeeMA,NagyWW,FournelleRA, Dhuru VB,TzenakisGK, Pechous CE. The effect of repeated torque on the ultimate tensile strength of slotted gold prosthetic screws. J Prosthet Dent 2002 Aug;88(2):176-182.

32. Mansour A, Ercoli C, Graser G, Tallents R, Moss M. Comparative evaluation of casting retention using the ITI solid abutment with six cements. Clin Oral Implants Res 2002 Aug;13(4):343-348.

33. Cibirka RM, Nelson SK, Lang BR, Rueggeberg FA. Examination of the implant-abutment interface after fatigue testing. J Prosthet Dent 2001 Mar;85(3):268-275.

34. Aboyoussef H, Weiner S, Ehrenberg D. Effect of an ant rotation resistance form on screw loosening for single implant-supported crowns. J Prosthet Dent 2000 Apr;83(4): 450-455.

35. Carr AB, Larsen PE, Papazoglou E, McGlumphy E. Reverse torque failure of screw-shaped implants in baboons: baseline data for abutment torque application. Int J Oral Maxillofac Implants 1995 Mar-Apr;10(2):162-174.

36. Diez JS, Brigagão VC, Cunha L, Neves AC, da Silva-Concilio LR. Influence of diamond like carbon-coated screws on the implant-abutment interface. Int J Oral Maxillofac Implants 2012 Sep-Oct;27(5):1055-1060.

37. Balfour A, O'Brien GR. Comparative study of ant rotational single tooth abutments. J Prosthet Dent 1995 Jan;73(1):36-43.

38. Khayat PG, Hallage PG, Toledo RA. An investigation of 131 consecutively placed wide screw-vent implants. Int J Oral Maxillofac Implants 2001 Nov-Dec;16(6):827-832.

39. Kitagawa T, Tanimoto $Y$, Odaki M, Nemoto K, Aida M. Influence of implant/abutment joint designs on abutment screw loosening in a dental implant system. J Biomed Mater Res B Appl Biomater 2005 Nov;75(2):457-463.

40. Tsuge T, Hagiwara Y. Influence of lateral-oblique cyclic loading on abutment screw loosening of internal and external hexagon implants. Dent Mat J 2009 Jul;28(4):373-381.

41. Weiss EI, Kozak D, Gross MD. Effect of repeated closures on opening torque values in seven abutment-implant systems. J Prosthet Dent 2000 Aug;84(2):194-199.

42. Available from: https://www.en.wikipedia.org/wiki/ Cathodic_arc_deposition\#Applications

43. Available from: https://www.en.wikipedia.org/wiki/ Physical_vapor_deposition\#Application

44. Available from: https://www.en.wikipedia.org/wiki/ Sputter_deposition

45. Ried K. Interpreting and understanding meta-analysis graphs: a practical guide. Aust Fam Physician 2006 Aug;35(8):635-638. 